\title{
Effect of organic carbon input on water and sediment quality in a lutjanid sea-cage farm
}

\author{
Efecto de la carga del carbón orgánico sobre la calidad del agua y el sedimento en \\ una granja de cultivo de lutjánidos en jaulas marinas \\ Miguel Ángel Flores ${ }^{1,4}$, Jesús T. Ponce-Palafox ${ }^{1,2}$, Sergio Castillo-Vargasmachuca ${ }^{1,3}$, \\ Heriberto Santana-Hernández ${ }^{4}$ and José Luis Arredondo-Figueroa ${ }^{5}$ \\ ${ }^{1}$ Posgrado en Ciencias Biológico Agropecuarias y Pesqueras (CBAP), Universidad Autónoma de Nayarit, \\ Ciudad de la Cultura Amado Nervo CP 63000, Tepic, Nayarit, México \\ ${ }^{2}$ Centro de Investigaciones Biológicas UAEM. Av. Universidad No. 1001. Col. Chamilpa, \\ Cuernavaca, CP 62209, Morelos, México \\ ${ }^{3}$ Escuela Nacional de Ingeniería Pesquera, Universidad Autónoma de Nayarit. Bahía de Matanchen, \\ San Blas, Nayarit, México \\ ${ }^{4}$ Instituto Nacional de Pesca. CRIP-Manzanillo Playa Ventanas S/N, Carretera Manzanillo a Campos, \\ Colonia México, CP 28200, Manzanillo, Colima, México \\ ${ }^{5}$ Planta de Producción Acuícola. Departamento de Hidrobiología, CBS. Universidad Autónoma Metropolitana \\ Iztapalapa, México D.F. \\ jesus.ponce@usa.net
}

\begin{abstract}
Resumen.- Se analizó el efecto de la entrada de carbón orgánico en la calidad del sedimento y su correlación con la interfase agua-sedimento y las condiciones hidrográficas en una granja de lutjánidos en jaulas marinas. Los resultados indican que se presenta una correlación de la temperatura del agua y el potencial de oxido reducción en la zona más profunda de la
\end{abstract}

\section{Introduction}

Sea cage fish generates significant amounts of organic and inorganic particulate material in the form of noningested feed and feces (Findlay \& Watling 1997). This input of particulate matter, especially organic component, would affect the marine environment causing eutrophication in water and sediments (Folke et al. 1994). The environmental impact of wasted feed depends upon physical processes, such as pellet degradation, settling velocity, water temperature and current speed (Findlay \& Watling 1997). Although faeces are significant sources of organic matter, food is believed to be the dominant source of organic carbon input added to marine cages fish farm (Silvert 1994).

The scale of environmental impact would depend on the amount of wastes generated by the sea cages, which is decided by the stocking density, quantity and type of feed, feed composition, size of pellets and the hydrographic conditions where cages are located. Depending on the variable scale of impact, the level of fish production that would be sustained in a particular columna de agua con el contenido de carbón orgánico (IOC) en el sedimento. Este resultado permite contar con una herramienta de fácil acceso para conocer en una forma indirecta el enriquecimiento orgánico del sedimento.

Palabras clave: Cultivo de peces, Lutjanidae, acuicultura

area is variable (Pawar et al. 2002). Several studies have been carried out around the world to evaluate the relationship between the produced wastes by sea cages and their impact on the water and sediment quality. There has been found a direct relationship between wastes and sediment eutrophication (Rapp et al. 2007). The objective of this study was to understand the effect of the organic carbon input on water and sediment quality in Lutjanidae sea floating net cages in Chipehua, Oaxaca, Mexico.

\section{Material and methods}

This investigation was developed at Chipehua Lutjanidae sea cages farm $\left(16^{\circ} 05^{\prime} 35.74^{\prime \prime} \mathrm{N}, 95^{\circ} 18^{\prime} 17.19^{\prime \prime} \mathrm{W}\right.$ and $\left.16^{\circ} 01^{\prime} 13.75^{\prime \prime} \mathrm{N}, 95^{\circ} 22^{\prime} 01.91^{\prime \prime} \mathrm{W}\right)$, located in Chipehua Bay in the western portion of the Itsmo de Tehuantepec, Oaxaca, Mexico. The annual water temperature in this area fluctuates from $18.0^{\circ} \mathrm{C}$ in winter to $30.0^{\circ} \mathrm{C}$ in summer. This farm initiated their operation in 2005 with ten cages of dimensions $5 \mathrm{~m}$ length $* 5 \mathrm{~m}$ wide $* 5 \mathrm{~m}$ deep. The fish species cultivated belong to the family Lutjanidae, including the red snapper, Lutjanus peru and the spotted rose snapper, Lutjanus guttatus. The juvenile fishes 
between 20 to $50 \mathrm{~g}$ of total weight are reared until they reach a marketing size of $500 \mathrm{~g}$. The growth period goes from February to August and from July to December, and the fish are retained in sea cages for a period of 6 or 7 months. Water and sediment samples were collected monthly from October 2005 to October 2006, in the farm area and a controlled station (Almadraba) was located $1,500 \mathrm{~m}$ off the sea cages farm. Sediment samples were collected with an Ekman grab sampler (Tokyo, Japan). Duplicate sediment sub-samples were utilized to analyze organic carbon (\%), using the equations for predicting soil organic carbon using loss-on-ignition method (Konen et al. 2002). Water samples were collected at $1 \mathrm{~m}$ above the bottom (at 11 and $13 \mathrm{~m}$ deep depending on the tide), and the following parameters were measured: water temperature $\left({ }^{\circ} \mathrm{C}\right)$, salinity (psu), $\mathrm{pH}$, redox potential $(\mathrm{mV})$, turbidity (NTU) and dissolved oxygen (DO) with a Troll 9500 Multi-parameter Analyzer (In-Situ Inc., USA). The composition of the dry pellet used as feed was obtained from the supplier (Camaronina 35, Purina). The organic carbon (OC) input per unit area of the farm per year was estimated from the data on yearly food input, farm average area under fish culture during the year, and the carbon content of food. OC input was calculated as $\mathrm{kgC} \mathrm{m}^{-2} \mathrm{yr}^{-1}$ through the following formula: $\mathrm{OC}=\left(\mathrm{FI} \mathrm{A}^{-1}\right) \times 0.01 \mathrm{C}$ : where FI = total food input per year (kg dry weight), $\mathrm{A}=$ area under culture $\left(\mathrm{m}^{2}\right)$ and $\mathrm{C}=$ carbon content of food (\%). In order to find any significant difference in water and sediment in both areas, statistically analysis for paired comparisons (paired $t$-test) was carried out. Significance was judged at the $5 \%$ level for all statistical tests performed (Montgomery 1984). Stations without significant difference in sediment and water parameters were grouped together.

\section{Results}

No significant differences were observed in the most of the sediment and water physicochemical parameters between the sea cage farm and Almadraba controlled area, which also has been found in South China by Hong-Hui et al. (2008). There was a significant difference $(P<0.05)$ only in turbidity between both sampling sites $(0.85 \pm 1.6$, farm and 4.6 $\pm 5.7 \mathrm{NTU}$, control). Mean temperature and dissolved oxygen (DO) were maintained at $25.4 \pm 4.7^{\circ} \mathrm{C}$ and $8.5 \pm 1.19 \mathrm{mg} \mathrm{L}^{-1}$, respectively. Values for $\mathrm{pH}$ and redox potential (Eh) were constant with a value near to $7.6 \pm 0.89$ and $164.64 \pm 47.10$, respectively. Mean salinity was maintained at $34.9 \pm 0.5$ psu. Mean organic carbon in sediment was maintained at $0.99 \pm 0.19 \%$. The food used in Chipehua Bay Farm is usually a mixture of dry feed (small pellets with 2.0 to $2.5 \mathrm{~mm}$ diameter) and raw fish (wet diet). The carbon content of food was $43.5 \%$, while nitrogen content was $8.5 \%$; resulting in a $\mathrm{C}: \mathrm{N}$ ratio of 5.1. The organic carbon content of dry pellets is approximately $43.5 \%$, while moist pellets varies from 46.5 to $50.3 \%$ (Pawar et al. 2002). The annual fish production of Chipehua Bay Farm fluctuates from 5 to 50 metric tons. The annual feed input per year varies from 9 to 90 metric tons (Table 1). The organic carbon input estimated ranged

Table 1

Estimated annual organic carbon input in the fish farm at three different fish density

Carga de carbón orgánico anual en la granja para tres densidades de peces

\begin{tabular}{cccccc}
\hline $\begin{array}{c}\text { Fish density } \\
\left(\mathrm{kg} \mathrm{m}^{-3}\right)\end{array}$ & $\begin{array}{c}\text { Production capacity } \\
\text { installed (\%) }\end{array}$ & $\begin{array}{c}\text { Production wet } \\
\text { weight (Ton) }\end{array}$ & $\begin{array}{c}\text { Feed input dry } \\
\text { weight (Ton) }\end{array}$ & $\begin{array}{c}\text { Area under } \\
\text { aquaculture }\left(\mathrm{m}^{2}\right)\end{array}$ & $\begin{array}{c}\text { Organic carbon input } \\
\left(\mathrm{kg} \mathrm{C} \mathrm{m}^{-2} \mathrm{yr}^{-1}\right)\end{array}$ \\
\hline 10 & 20 & 5 & 9 & 225 & 17.40 \\
10 & 40 & 10 & 18 & 525 & 14.91 \\
10 & 60 & 15 & 27 & 825 & 14.24 \\
10 & 80 & 20 & 36 & 1125 & 13.92 \\
10 & 100 & 25 & 45 & 1425 & 13.74 \\
15 & 20 & 15 & 13.5 & 225 & 26.10 \\
15 & 40 & 22.5 & 27 & 525 & 21.35 \\
15 & 60 & 30 & 50.5 & 1125 & 20.88 \\
15 & 80 & 37.5 & 67.5 & 1425 & 20.61 \\
15 & 100 & 10 & 18 & 225 & 34.80 \\
20 & 20 & 20 & 36 & 525 & 29.83 \\
20 & 40 & 30 & 54 & 825 & 28.47 \\
20 & 60 & 40 & 72 & 1125 & 27.84 \\
20 & 80 & 50 & 90 & 1425 & 27.47 \\
20 & 100 & & & \\
\hline
\end{tabular}


from 13.7 to $34.8 \mathrm{kgC} \mathrm{m}^{-2} \mathrm{yr}^{-1}$. A negative linear relationship between redox potential and organic carbon in the sediment was observed $\left(R^{2}=0.83\right)$ during the sampling period. The slope value of the regression line was of 156.87. Similarly, dissolved oxygen $\left(R^{2}=0.76\right)$ showed a negative correlation with organic carbon, and in this case the regression line exhibited a slope of -3.75 (Fig. 1). The fish metabolism increased in summer days due high water temperature causing an increase in food consumption. A positive relationship between water temperature and carbon organic in sediment was registered $\left(R^{2}=0.84\right)$, and the redox potential showed a negative linear correlation with water temperature $\left(\mathrm{R}^{2}=\right.$ 0.73) (Fig. 1). In general, the results indicated a relationship between the physicochemical parameters of the water and the concentration of organic carbon in sediment. In such a way that a widespread model of multiple regression was built for the sustainable handling of the culture of Lutjanidae in Chipehua farm, using the data of sediment of the area of the cages and the physicochemical parameters from the column of water to the bottom. For the model independent variables were temperature and redox potential in water and dependent variables was the concentration of organic carbon (OC), in sediment, the results were expressed as the following equation:

$$
\mathrm{OC}=1.557+0.070 \mathrm{~T}+-0.053 \mathrm{RP}\left(\mathrm{R}^{2}=0.86\right),
$$

where OC = organic carbon content of the sediment (\%), $\mathrm{T}=$ water temperature $\left({ }^{\circ} \mathrm{C}\right)$ and $\mathrm{RP}=$ the redox potential $(\mathrm{mV})$.
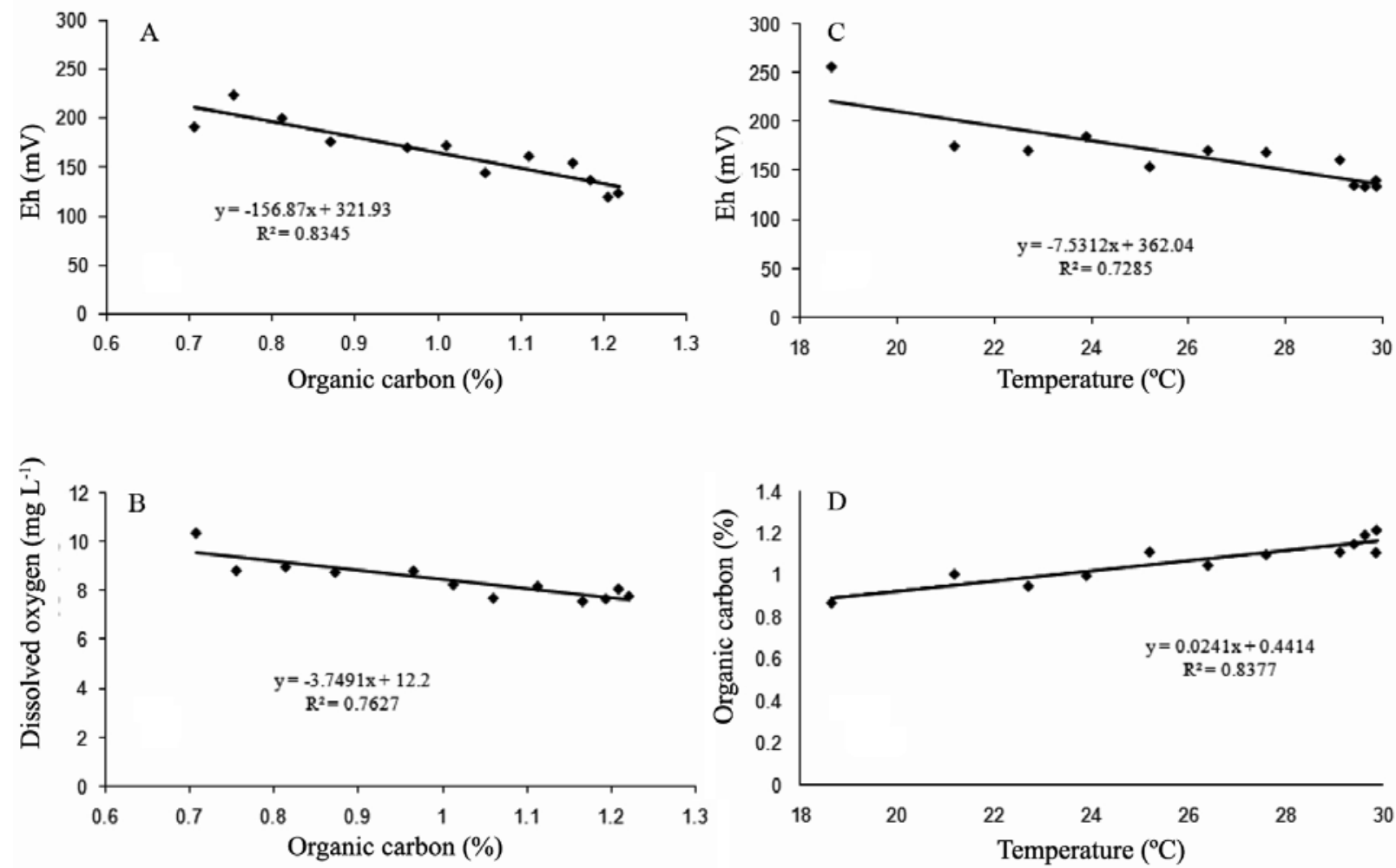

Figure 1

A) Linear regression between redox potential (Eh) and organic carbon in sediment (\%), B) between dissolved oxygen water $\left(\mathrm{mg} \mathrm{L}^{-1}\right)$ and organic carbon in sediment $\left.(\%), \mathrm{C}\right)$ between redox potential $(\mathrm{Eh})$ and water temperature $\left({ }^{\circ} \mathrm{C}\right)$, D) between organic carbon in sediment $(\%)$ and water temperature $\left({ }^{\circ} \mathrm{C}\right)$

A) Regresión lineal entre el potencial redox (Eh) y carbón orgánico en el sedimento (\%), B) entre oxígeno disuelto (mg $\mathrm{L}^{-1}$ ) y carbón orgánico en el sedimento (\%), C) entre el potencial redox (Eh) y la temperatura del agua $\left({ }^{\circ} \mathrm{C}\right)$,

D) entre carbón orgánico en el sedimento y la temperatura del agua $\left({ }^{\circ} \mathrm{C}\right)$ 
This adjusted $\mathrm{R}^{2}$ square value gives the most useful measure of the success of our model. We have an adjusted $\mathrm{R}^{2}$ square value of 0.86 so we can say that our model has accounted for $86 \%$ of the variance in the criterion variable.

\section{Discussion}

Maldonado et al. (2005) found that medium-sized fish farms located on semi exposed western Mediterranean coasts have fewer environmental impacts than traditional fish farms located in shallow, sheltered sites. Impact characterization in these new farms may require refinement of the standard approach to deal with rapid dispersal of effluents and sub-lethal levels of environmental disturbance. Similar results were found in small farms in this study. The changes in redox potential showed a linear relationship with the organic carbon concentration in the sediments of sea cages area as well as water temperature. In a study conducted by Holmer \& Kristensen (1994) on sediment metabolism, a strong correlation was observed in a sea cage farm between total anaerobic metabolism ( $\mathrm{TCO}_{2}$ production) and input of feed pellets and the water temperature explained the $40 \%$ of this behavior. Various studies had reported that the input of organic matter affects the seasonal variation of the major biochemical cycles (Hargrave et al. 1993). Pawar et al. (2002) found that the acid volatile sulphide -S content is strongly correlated with the water temperature and the seasonal organic carbon input. In this study, the redox potential in water and the organic carbon content in sediment were strongly correlated with water temperature, this can be explained due the increase of fish metabolism generated by high temperatures in summer causing a higher demand of food input, resulting in an increase of the organic carbon matter quantity in the sediment and provoking higher sulfate reduction rates and an increase of organic carbon content in the sediment and a decrease of redox potential in the column of water. The redox potential was highly correlated with the organic carbon in sediment, than water temperature. Thus, among the indicators used to evaluate environmental impact of the sea cage fish farm, redox potential proves to be a better indicator.

If we compare the organic carbon input at three densities used in this study (10, 15 and $20 \mathrm{~kg} \mathrm{~m}^{-3}$ ) (Table 1 ), it can be observed that when the production cage area is increasing from 10 to $100 \%$, the organic carbon input in the system for area unit diminishes around 21\% (17.4 to $13.7,26.1$ to 20.6 and 34.8 to $27.5 \mathrm{kgC} \mathrm{m}^{-2}$ year $^{-1}$, respectively). This supports the idea of maintaining $10 \mathrm{~m}$ of distance among each cage. The pellets used for the Lutjanidae cultivation in the floating sea-cages had an interval of 2.0 to $2.5 \mathrm{~mm}$ length, which are considered as small pellets. A sinking velocity of $14 \mathrm{~cm} \mathrm{~s}^{-1}$ for large pellets and $4 \mathrm{~cm} \mathrm{~s}^{-1}$ for feces was reported in a study carried out by Hevia et al. (1996). Thus, in a particular location, the area over which the feces can be dispersed will be three fold large than dry pellets. As the size of the dry powder feed and small pellets (2.5 $\mathrm{mm}$ in diameter) is comparable to that of the fecal particles, we can assume a same sinking velocity for the dry powder feed and small pellets. With this assumption, for the same amount of food input, the POC load in the sediment per unit area per unit of time is three fold higher at the Chipehua farm than in farms using large pellets. This demonstrates the importance of the pellets size of food, as one of the factors to be considered when determining the maximum permissible level of food input at a particular farm so that the sediment quality standards are maintained. Diver observation and the absence of dissolved hydrogen sulphide in the water overlying sediments revealed low benthic impacts due to the high speed of the current and to the low aquaculture activity in the area. These results may be explained partly by the large number of fish present around the cages feeding on farm wastes, which has also been reported by Dougall \& Black (1999). The equations of multiple regression analysis between the organic carbon concentration in sediment, water temperature and redox potential, can be used as a predictive model and as a tool for effective farm management in the future sustainable aquaculture. The prediction allows us to know the organic carbon input in sediment, over a range of a hypothetical seasonal mean water temperature. This model incorporates the two most important factors determining the farm sediment quality, the water temperature and organic carbon input, thus making it a very important tool for sustainable management of the fish farm. It would assist in deciding if the food input in a particular season can still be maintained at the same level or has to be decreased in order to meet the sediment quality standards. In the present study, relationship between sediment quality and food input at a particular site could be established. In order to construct a generalized model for sustainable management of fish farms, precise data on the hydrographic conditions of different areas, detailed reports on the food input and sedimentation rate are needed.

\section{Literature cited}

Dougall NM \& KD Black. 1999. Determining sediment properties around a marine cage farm using acoustic ground discrimination. Aquaculture Research 30: 451-458.

Findlay RH \& L Watling. 1997. Prediction of benthic impact for salmon net-pens based on the balance of benthic oxygen supply and demand. Marine Ecology Progress Series 155: 147-157. 
Findlay RH, L Watling \& LM Mayer. 1995. Environmental impact of salmon net-pen culture on marine benthic communities in Maine. A case study. Estuaries 18: 145-179.

Folke C, N Kautsky \& M Troell. 1994. The cost of eutrophication from salmon farming: implications for policy. Journal of Environmental Management 40: 173-82.

Hargrave BT, DE Duplisea, E Pfeiffer \& DJ Wildish. 1993. Seasonal changes in benthic flux of dissolved oxygen and ammonium associated with marine cultured Atlantic salmon. Marine Ecology Progress Series 96: 249-257.

Hevia M, H Rosenthal \& RJ Gowen. 1996. Modelling benthic deposition in fish cages. Journal of Applied Ichthyology 12: 71-74.

Holmer M \& E Kristensen. 1994. Organic matter mineralization in organic rich sediment: experimental stimulation of sulphate reduction by fish food pellets. FEMS Microbiology Ecology 14: 33-44.

Hong-Hui H, L Qing, J Xiao-Ping \& G Gen-Xi. 2008. Seawater pollution monitoring in a net cage fish farm in Daya Bay, South China. In: Institute of Electrical and Electronics Engineers (eds). Bioinformatics and biomedical engineering, pp. 3604-3608. Institute of Electrical and Electronics Engineers, Shanghai.

Konen ME, PM Jacobs, CL Burras, BJ Talaga \& JA Mason. 2002. Equations for predicting soil organic carbon using loss-on-ignition for North Central U.S. Soils. Soil Science Society of American Journal 66: 1878-1881.
Maldonado M, MC Carmona, Y Echeverrýa \& A Riesgo. 2005. The environmental impact of Mediterranean cage fish farms at semi-exposed locations: does it need a reassessment. Helgoland Marine Research 59: 121-135.

Montgomery DC. 1984. Design and analysis of experiment, 538 pp. John Wiley \& Sons, New York.

Pawar V, O Matsuda \& N Fujisaki. 2002. Relationship between feed input and sediment quality of the fish cage farms. Fisheries Science 68: 894-903.

Rapp P, WR Ramirez, JA Rivera, M Carlo \& R Luciano. 2007. Measurement of organic loading under and openocean aquaculture cage, using sediment traps on the bottom. Journal of Applied Ichthyology 23(6): 661-667.

Silvert W. 1994. Modelling benthic deposition and impacts of organic matter loading. In: Hargrave BT (ed). Modelling benthic impacts of organic enrichment from marine aquaculture. Canadian Technical Report of Fisheries and Aquatic Sciences 1949: 1-18.

Stumm W \& JJ Morgan. 1970. Aquatic chemistry, an introduction emphasizing chemical equilibria in natural waters. In: Riley JP \& R Chester (eds). Chemical oceanography, Vol. 6: 10-11. Academic Press, New York.

Recibido el 27 de mayo de 2008 y aceptado el 12 de diciembre de 2008 